\title{
O PROCESSO JUDICIAL PREVIDENCIÁRIO, JUSTIÇA QUANTITATIVA E A SATISFATIVIDADE DA JURISDIÇÃO
}

\author{
Melquíades Peixoto Soares Neto ${ }^{42}$
}

Recebido em: 18/11/2018

Aprovado em: 26/02/2019

\begin{abstract}
RESUMO
A jurisdição não deve mais atender somente o interesse subjetivo das partes, mas, na construção da decisão judicial, toda a sociedade tem interesse. Em matéria de Direitos Sociais Previdenciários a atividade do juiz deve sobrepor a materialização e construção do Direito em face da celeridade e eficiência processual, sob pena de não solucionar o conflito nem restabelecer a paz social. Neste aspecto, a tutela jurisdicional deve considerar a impossibilidade de retrocesso em matéria social, bem como os influxos neoliberais na construção de um conceito de celeridade, observando que o atingimento da decisão judicial perfaz todo o corpo social, de forma que se o indivíduo não for efetivamente protegido pelo Judiciário, de nada adiantará o atingimento de metas e o julgamento massivo de processos. Desta forma, o presente estudo, através de pesquisa bibliográfica e análise de dados estatísticos, considera o fator satisfatividade e celeridade em face da necessidade de um Direito á Previdência materializado e reconstruído.
\end{abstract}

Palavras-chave: Direito à Previdência. Satisfatividade. Celeridade. Processo.

\section{INTRODUÇÃO}

O ideal de um Poder Judiciário eficiente e célere é o que rege de forma mais prevalente o fornecimento de uma tutela jurisdicional nos dias atuais.

Este aspecto se torna ainda mais evidente no que se refere à discussão que envolve direitos postos em análise no Judiciário através de demandas numerosas, massivas.

O Direito Social à Previdência, especificamente as prestações materiais encartadas no rol de benefício previdenciários estabelecidos pelo Regime Geral são direitos que se encontram nesta situação. Situados em um palco de grande insatisfação popular, há um grande

\footnotetext{
${ }^{42}$ Mestrando em Direito pela Universidade Federal do Rio Grande do Norte - UFRN. Especialista em Direito Constitucional e Tributário pela Universidade Potiguar - UnP. Advogado.
} 
número de ações judiciais que buscam a revisão de atos administrativos de indeferimento ou de deferimento equivocado de benefícios, o que compromete em grande parte a atuação da Justiça Federal.

Embora haja uma resposta satisfatória no que se refere ao tempo de transcurso do processo, é dizer, no tempo de resposta dos pleitos tratados, é preciso refletir acerca da sobreposição do ideal da celeridade e eficiência em face da necessidade de uma tutela jurisdicional satisfativa e materializadora.

A satisfação não estaria no mero resultado da demanda judicial, mas sim na qualidade da resposta apresentada para as partes e para a sociedade, de forma a satisfazer não só os interesses dos envolvidos, mas esvaziar completamente o conflito, restabelecendo o status de paz social.

O presente estudo visa demonstrar a sobreposição da celeridade processual em face da efetividade processual, e como esta sobreposição prejudica o processo judicial que versa sobre demandas previdenciárias, não solucionando, efetivamente, os conflitos postos em análise, mas estabelecendo uma resposta meramente paliativa para o contexto social.

A demonstração se dá a partir da análise do caráter essencial do Direito Previdenciário, como Direito Social, bem como, diante da sua essencialidade, da impossibilidade de retrocesso no seu âmbito, como o retrocesso que ocorre a partir da sobreposição referida.

Demonstrada a essencialidade do Direito à Previdência, apresenta-se o quadro de posicionamento do Poder Judiciário, no que se refere à necessidade de atuação satisfativa, indo além da confirmação da situação jurídica analisada na relação processual, mas estabelecendo uma decisão judicial que possa interferir efetivamente na sociedade, sanando o conflito, independentemente do interesse subjetivo das partes ser atendido ou não.

Para tanto, foi realizado estudo bibliográfico com base em obras que tratam do tema, bem como análise de estatísticas do Conselho Nacional de Justiça - Justiça em Números, demonstrando o grande número de demandas judiciais que versam sobre o Direito à Previdência e a relevância que o tema possui.

2 PREVIDÊNCIA SOCIAL. LIBERDADE E IGUALDADE: DEFINIÇÃO DO QUE MOVE A FUNÇÃO JUDICIAL DO ESTADO NESTE VIÉS 
Antes de mais nada, é necessário reconhecer que o processo previdenciário possui um disciplinamento autônomo em face dos demais ramos do processo civil, e que, por isso, merece destaque no que diz respeito às peculiaridades do seu procedimento, em especial na produção da prova. Assim, não atende os fins para os quais foi disciplinado caso haja aplicação irrestrita das normas ordinárias do processo civil.

$\mathrm{Na}$ esmagadora maioria das demandas judiciais que tratam acerca das prestações previdenciárias, se versa sobre matéria de fato, que demanda a produção de prova pericial e testemunhal. Neste sentido, basta observar as estatísticas do Conselho Nacional de Justiça CNJ sobre o tema, onde se demonstra que na maioria dos casos discute-se a concessão/restabelecimento de benefícios por incapacidade, onde se analisa a condição médica do autor, ou mesmo o exercício do labor ou vertimento de contribuições, para averiguar a sua qualidade de segurado.

Ao lado desta característica específica do processo judicial previdenciário, neste ponto, é necessário destacar dois elementos justificadores do caráter autônomo desta disciplina: a) a natureza essencial e urgente do provimento jurisdicional previdenciário; b) reconhecida pobreza e marginalização a ser combatida na nação brasileira.

O primeiro elemento se revela a partir da análise do direito material que, ao se relacionar com a Previdência Social, especificamente no que diz respeito ao Regime Geral, aparece como prestações materiais urgentes e indisponíveis em face do segurado. É dizer, bate-se as portas do Poder Judiciário não apenas sob a alegação de ofensa ou perigo de ofensa a algum direito, mas sempre diante de um risco social evidente, que insere o segurado em uma situação de desamparo e marginalização social.

Destaque-se, neste sentido, que as prestações materiais previdenciárias têm o papel de amparo dos dependentes do segurado ou substituição de sua manutenção material em situações de impossibilidade de auferimento de renda através do labor, pela a ocorrência de qualquer risco social dentre aqueles enumerados no art. 201 da Constituição Federal.

Assim, o fornecimento de uma tutela jurisdicional inefetiva, morosa ou mesmo discrepante com a realidade do jurisdicionado, mais do que inviabilizar o auferimento de uma prestação material previdenciária, inevitavelmente, causará danos graves, ou mesmo irreparáveis, ao segurado, de forma consequencial. E vai além, os danos ultrapassam a pessoa do segurado e atingem diretamente a sua família, a condição de dependentes.

Indo além, o Estado-juiz, ao dar uma resposta diante do pleito do segurado, nas situações em que entende pela procedência ou não, deve oferecer uma manifestação clara e resolutiva da questão. Em especial nas situações onde a decisão seja de improcedência, o 
segurado deve sair da sua posição de parte, para fora do processo, devidamente esclarecido acerca do seu rumo, se tentará retornar ao mercado de trabalho, se tentará se profissionalizar ou especializar para se adequar às suas limitações, não incapacitantes, mas condicionantes da realização das suas atividades, ou mesmo se prosseguirá com sua pretensão na via recursal ou com o ajuizamento de uma nova ação.

No que se refere ao segundo elemento, não pode passar despercebida a previsão constitucional expressa que reconhece o Brasil como um país problematizado a partir da existência de pobreza e marginalização a serem combatidas (art. $3^{\circ}$, III, da Constituição Federal). Destaca-se, neste sentido, a utilização pelo constituinte originário do verbo “erradicar”, como uma pretensão ambiciosa, senão utópica, em face da situação de qualquer nação.

Ao encarar, a partir deste dispositivo constitucional, a Previdência Social, o intérprete não pode alocar o Regime Geral como um problema, mas sim como uma solução. Sempre se busca, no âmbito das reformas legislativas, a mitigação dos gastos com a Previdência Social, modificando-se as normas que regulam a concessão dos benefícios, endurecendo os requisitos para tanto, contudo, sem observar um aspecto fundamental, é dizer, a razão pela qual tantas pessoas procuram a cobertura previdenciária no Brasil. A observância deste aspecto não pode ser encarado de forma diferente no processo judicial.

Com a judicialização da problemática a análise deve ser ainda mais pormenorizada, sempre com observância do porque o segurado pleiteia a concessão de um benefício previdenciário. O Brasil é um país pobre e desigual, sendo que a resolução desta problemática, no que diz respeito à Previdência Social, não reside somente no aspecto da concessão propriamente dita de prestações materiais previdenciárias, como substituição dos rendimentos do segurado, mas também deve ser considerada a questão da reinserção do segurado no mercado de trabalho, onde, através do labor, poderá não somente auferir renda, mas contribuir para o Regime Geral e ajudar outras pessoas que necessitam da proteção previdenciária.

Em suma, é preciso pensar a decisão judicial para além do processo, quais as suas consequências fora da relação jurídica processual, qual será o destino do segurado ao receber ou não a prestação previdenciária. Trata-se essencialmente de uma "função social" da decisão judicial (*), função esta não construída isolada e exclusivamente pelo magistrado, mas também pelas partes, especialmente pelo destaque de protagonismo aperfeiçoado pela novel legislação processual, que deve ser adequada ao processo judicial previdenciário. 
2.1 Previdência como Direito Fundamental, portanto, inafetável por retrocessos

Observada a definição da essência dos Direitos Fundamentais, especificamente dos valores que são indissociáveis da existência desta categoria de direitos, cabe estabelecer, neste momento, qual o vetor de atuação do ente estatal no que se refere ao Direito à Previdência Social, bem como a expressão da liberdade e igualdade neste elemento da Seguridade Social.

Os Direitos Sociais referem-se à questões básicas que integram e perfectibilizam a dignidade humana, através de um contorno, sobre este fundamento, de "mínimo social" (RAWLS, 1980, p. 15) ou "mínimo existencial" (BOROWSKI, 2003, p. 20), abrangendo valores econômicos, sociais e culturais.

A Seguridade Social é erigida ao patamar de Direito Humano, integrando a Declaração Universal dos Direitos Humanos ${ }^{43}$. Outras normas internacionais estabelecem o caráter de Direito Fundamental da Seguridade Social, como o Pacto Internacional de Direitos Econômicos, Sociais e Culturais, do Protocolo Adicional à Convenção Americana sobre Direitos Humanos em Matéria de Direitos Econômicos, Sociais e Culturais (Protocolo de San Salvador), bem como a Declaração Sociolaboral do Mercosul e do Convênio IberoAmericano de Seguridade Social (SHWARZ; FLORÊNCIO TOMÉ, 2017, p. 03).

É preciso estabelecer a Previdência Social no seu devido lugar, justamente para fundamentar o papel do Estado, através dos seus poderes/funções, na proteção inabalável deste direito.

Inicialmente é preciso rememorar que a Previdência Social é um dos elementos que integram a Seguridade Social, a qual abrange um tripé, também integrado pela Saúde e Assistência Social.

Não há como negar, neste sentido, que a Previdência Social age em ambientes de desigualdade e de ofensa à liberdade do indivíduo (TAVARES, 2011, p. 125), em seu aspecto material. Ora, não há como prever as intemperes da vida, as mazelas sociais. Mesmo o indivíduo mais precavido, mais coerente e razoável nos cuidados com a sua própria existência, pode ser vítima de um risco social, ainda que previsível, mas incerto.

Este é justamente o ponto em que a Previdência Social entra em cena. Não há como evitar os riscos sociais, mas há como combater ou mitigar os respectivos efeitos, garantindo ao cidadão a manutenção da sua existência social (AIRES FILHO, 2014, p. 162) mesmo em

\footnotetext{
${ }^{43}$ Art. 22 Todo ser humano, como membro da sociedade, tem direito à segurança social, à realização pelo esforço nacional, pela cooperação internacional e de acordo com a organização e recursos de cada Estado, dos direitos econômicos, sociais e culturais indispensáveis à sua dignidade e ao livre desenvolvimento da sua personalidade.
} 
uma situação de instabilidade na sua vivência. Não por outra razão, o art. 201 da Constituição Federal define eventos que são, em sua maioria, incertos, sendo que os que possuem uma certeza maior, são inevitáveis, como a velhice e a morte.

A Previdência Social interfere na relação do indivíduo com o risco social, o qual impede o auto sustento do cidadão através do trabalho. A proteção se torna mais incidente em situações em que o próprio trabalho do cidadão provoca riscos além dos comuns para a sua vida, integridade física ou saúde, ou mesmo nas situações em que o cidadão, mesmo sendo portador de uma deficiência, permanece no exercício de atividade laboral. Nestes casos, a Previdência estabelece uma flexibilização ${ }^{44}$ dos requisitos, permitindo, por exemplo, a concessão de aposentadoria em tempo menor e com mais vantagens (ex: não incidência do fator previdenciário).

É importante estabelecer, portanto, em face da Previdência Social, um papel determinante para a manutenção da sociedade. O humano tem existência temporal limitada e se submete a uma série de riscos na sua vivência social. Alocar o Estado distante deste fato, em uma posição liberal, abstencionista, é retroceder par ao século XVIII e negar toda a evolução do constitucionalismo e dos Direitos Fundamentais.

Nos dias atuais, a vivência comprova que a relação do Estado com a Previdência Social é eminentemente conflitiva, se firmando em uma separação por um escudo relacionado a um fator econômico. É dizer, põe-se em primeiro plano a manutenção da estrutura estatal, em submissão a um segundo plano integrado pelo indivíduo submetido a um risco social. Em poucas palavras, condiciona-se a legalidade/legitimidade da Previdência à eficiência/eficiência econômica (CANOTILHO; STRECK, 2006, p. 22).

E não só isso. A conduta estatal no que se refere à execução da Previdência, e aqui especifica-se a fala volvendo-se para o Poder Executivo, sofre a incidência de organizações econômicas e de grande influência no mercado financeiro, provocando medidas de austeridade fiscal, mitigação de gastos sociais e condução de fatores econômicos em decisões políticas e, inclusive, judiciais (MORAIS, 2002, p. 29).

Esse ambiente de constante "emergência econômica" (BERCOVICCI, 2004, p. 179) é fértil para a instituição executiva de medidas que retrocedem os Direitos Sociais, em especial a Previdência, com a criação de mecanismos que dificultam o acesso a proteção

\footnotetext{
${ }^{44}$ É o que se observa do art. 201, §1 $1^{\circ}$, da Constituição Federal: É vedada a adoção de requisitos e critérios diferenciados para a concessão de aposentadoria aos beneficiários do regime geral de previdência social, ressalvados os casos de atividades exercidas sob condições especiais que prejudiquem a saúde ou a integridade física e quando se tratar de segurados portadores de deficiência, nos termos definidos em lei complementar. (Redação dada pela Emenda Constitucional no 47, de 2005)
} 
previdenciária, bem como reduzem o campo de proteção estabelecido inicialmente. A partir deste ambiente, os Direitos Sociais são desentrincheirados, alocando-se em uma situação de vulnerabilidade e, portanto, sendo o primeiro alvo de medidas de restrição econômica estatal.

Em sua maioria, as restrições e mitigações propostas se firmam no postulado do equilíbrio financeiro-atuarial, o qual, inclusive, é elencado pela própria Constituição Federal, assim como a necessidade de prévia fonte de custeio ${ }^{45}$. Esse postulado, contudo, como de forma brilhante esclarece José Antonio Savaris (2010, p. 13), é um “imediatismo de feição utilitarista que se manifesta na redução ou sacrifício atual de direitos e pessoas desfavorecidos em favor da maximização do bem-estar coletivo".

Como Direito Fundamental, é preciso observar a Previdência Social em face da vedação do seu retrocesso, em conjunto com a sua historicidade. Ora, uma conquista regada por lutas e dificuldades, resultado de toda uma evolução histórica que perpassou, inclusive, por duas grandes guerras, deve ser considerada como fator determinante para a manutenção do bem estar social. Obviamente, as adequações poderão ser propostas de acordo com a evolução social, afinal de contas, a sociedade muda o Direito. Não é o aparato estatal sancionador que, incidindo sobre a sociedade faz com que, de forma imediatista, haja mudanças, mas a vontade social que dita o ritmo das oscilações provocadas pela norma (WEBER, 2011, p. 41).

Neste ambiente, não se defende que a Previdência Social seja blindada contra mudanças, inclusive aquelas que possam adequar o sistema de prestações materiais (benefícios) de acordo com as peculiaridades do momento em que o Estado vive, é dizer, no aspecto econômico. Ocorre que estas mudanças têm de ser a última ratio, o ponto sensível a ser tocado somente em caso de imprescindibilidade, de não haver outra solução, mas não ficar a mercê de uma constante crise econômica que só vem a afetar, no seu combate, os indivíduos submetidos aos maiores riscos sociais e de forma mais constante, ou seja, aqueles que estão nas classes sociais mais baixas.

É preciso compreender a previdência como essencial, mas não como um ônus que o Estado tem de arcar por herança de uma Constituição adjetivada como cidadão por medo ou exagero em face do regime anterior. Tão essencial é este escopo de proteção que a maior parte da sociedade é atingida pelos seus efeitos.

Há, portanto, o impedimento de desconstituição de conquistas no que se refere aos Direitos Fundamentais, em especial os Sociais (MENDES; COELHO, GONET BRANCO,

\footnotetext{
${ }^{45}$ Art. 195 , §5 , da CF: Nenhum benefício ou serviço da seguridade social poderá ser criado, majorado ou estendido sem a correspondente fonte de custeio total.
} 
2002, p. 127-128), admitindo-se mudanças, de acordo com as peculiaridades do momento social e econômico vivenciado pela comunidade. Mas que fique claro que essas mudanças devem ser imprescindíveis e a última saída para o reequilíbrio econômico, político e institucional do Estado. O caráter de imprescindibilidade e de exaurimento de outros meios de combate à situação de crise se justifica pela íntima relação que a vedação do retrocesso, no âmbito dos Direitos Sociais, tem com os princípios do Estado Democrático e Social de Direito; da dignidade humana; da máxima eficácia e efetividade das normas constitucionais; da proteção dos direitos adquiridos, do ato jurídico perfeito e da coisa julgada; da proteção da confiança e da segurança jurídica (SARLET, 2007, p. 457-460).

A proibição do retrocesso, neste sentido, se vincula diretamente ao ideal do constitucionalismo dirigente, como corolário da garantia da igualdade material, combatendo as desigualdades e efetivando, ao máximo, os Direitos Sociais (CANOTILHO, 2006, p. 215).

Assim, a conduta estatal deve observar o vetor de aperfeiçoamento e evolução da Previdência Social, garantindo a sua universalidade, de forma cada vez mais abrangente, não permitindo situações de mitigação ou redução de garantias materiais prestacionais. Este deve ser o vetor interpretativo e executivo do Estado, mas não o de enxergar a Previdência Social como problema e o primeiro ponto a ser tratado, e sim reservar eventuais mudanças neste campo apenas para situações inevitáveis e drásticas.

A vedação do retrocesso se aplica, em especial, no âmbito de atuação do Estado em suas funções Executiva e Legislativa. A vedação emite efeitos em face da competência legislativa estabelecida no art. 21, XXIII, da Constituição Federal, ao estabelecer a competência legislativa privativa da União no que se refere à Seguridade Social.

Assim, na regulamentação do sistema de Seguridade Social, o que inclui a Previdência Social, o Estado não poderá, através de norma infraconstitucional, estabelecer o enrijecimento ou piora do status aquisitivo de prestações previdenciárias, isto é, estabelecer requisitos mais dificultosos para o alcance dos benefícios, ou mesmo para a sua manutenção. Obviamente, essas modificações poderão ocorrer em casos extremos de imprescindível mudança para fins de combate à situação atípica de crise financeira e atuarial do sistema.

Ocorre que no momento atual o Estado brasileiro não vem observando a necessidade de imprescindibilidade das mudanças em face da Previdência Social, adotando condutas que dificultam o acesso do segurado à proteção previdenciária, sem tomar todas as medidas estritamente necessárias para o combate da crise do sistema, o que poderia mitigar ou mesmo desconsiderar essas mudanças. 
Esta atuação do ente estatal força a atividade criativa e concretista do Poder Judiciário, indo além da jurisdição constitucional propriamente dita, mas atuando em situações individuais através do alargamento da proteção previdenciária, inobstante vedação legal ou conduta negativa da Administração Pública, ou mesmo interpretando normas previdenciárias em favor do segurado. Institui-se, portanto, um ambiente de conflito, de embate entre o Poder Executivo e o Poder Judiciário, o que prejudica o funcionamento institucional das duas funções referidas, bem como o segurado, o qual acaba por ter no Judiciário uma figura de confirmador ou verificador do seu direito em face do Regime Geral de Previdência Social.

2.2 Poder Judiciário e Previdência Social. Necessidade de uma função satisfativa, não somente confirmadora

Os contornos atuais da processualística civil, a qual abrange o processo previdenciário, não mais admitem a função jurisdicional como uma mera ferramenta de resolução de conflitos, solucionando a lide em limites particulares.

$\mathrm{Na}$ realidade, a decisão judicial, seja em que sentido for, sempre possui um escopo social (ARAUJO CINTRA; GRINOVER; DINAMARCO, 2015, p. 46), que se fundamenta essencialmente na própria finalidade da existência do Estado, que é conferir a paz social, de forma a permitir a coexistência dos indivíduos, não livres, em termos absolutos, dos conflitos, mas capazes de solucioná-los reafirmando a convivência harmônica em sociedade, através de um poder que é uno, dotado de imperatividade, instrumentalizado por funções (DINAMARCO; LOPES, 2018, p. 77).

Ao Poder Judiciário não cabe a expressão da tutela jurisdicional de forma isolada das partes, mas sim a construção da decisão judicial por meio de uma conduta cooperativa, através daquele que representa a jurisdição estatal, que é o juiz, e dos demais sujeitos que integram a relação processual, o autor e o réu. A cooperação na construção da resposta jurisdicional confere uma maior legitimidade e satisfatividade da atividade do Poder Judiciário, pois o desenvolvimento de uma decisão judicial proveniente da atuação e, portanto, da ciência de todos os afetados pelos seus efeitos, lhe fornece uma maior aceitabilidade. Uma decisão judicial proferida distante da relação processual, do interesse e da ciência dos afetados, não soluciona o conflito, mas apenas o camufla (MOREIRA, 1993, 243).

A sociedade, portanto, influencia diretamente na fabricação da decisão judicial, que possui um papel mais do que solucionador, no que se refere aos conflitos, mas, 
essencialmente, um papel reconstrutivo, do Direito e da própria sociedade (DIDIER JÚNIOR, 2017, p. 620).

Ao se deparar com um conflito, o Poder Judiciário tem em suas mãos uma situação de crise. Em matéria de Direitos Fundamentais esse papel se torna ainda mais relevante, na medida em que se faz essencial uma concepção democrática de poder (TARUFFO, 2015, p. 237), no que se refere à atividade jurisdicional, permitindo a participação das partes e de toda a sociedade na resposta a esta crise.

$\mathrm{Na}$ fundamentação da decisão judicial não se examina de onde advieram os argumentos/fundamentos ou mesmo as provas. O que se observa é um conjunto de fatos e alegações que estabelecem na relação processual uma construção fictícia de uma relação material, transmudada para o processo, porém, não necessariamente absoluta com a realidade. A análise dos elementos probatórios e dos fatos se dá de maneira uniforme, concentrada (princípio da unidade da prova), observando mais o interesse social no restabelecimento da situação de paz social do que o conflito das partes propriamente dito. A adoção ou rejeição dos argumentos ocorre, portanto, de forma fundamentada e com base na unidade do plexo de relações fático-probatórias (SILVA, 2006, p. 340).

Não por outra razão, o Novo Código de Processo Civil (Lei 13.105/2015) traz em seu bojo os princípios da boa-fé e da cooperação, inclusive fornecendo as partes o poder de disposição por meio dos negócios jurídicos processuais (art. 190), fortalecendo e aperfeiçoando a influência de tais sujeitos na configuração da decisão judicial.

Ademais, no sistema de precedentes, ao lado da permissão de improcedência liminar do pedido com base em decisões judiciais integrantes do bloco de precedentes (art. 332), na superação, modificação ou construção do precedente, permite a intervenção direta de sujeitos distintos das partes, mas que representam interesses de parcela da sociedade, garantindo um caráter democrático na configuração do precedente como elemento vinculante.

Permite-se, ainda, a rescisão de sentença ou desconstrução da exigibilidade de título executivo judicial, quando a sentença se funda em norma declarada inconstitucional em sede de controle de constitucionalidade qualificado, difuso ou concentrado, pelo Supremo Tribunal Federal, ou mesmo deixa de aplicar norma declarada constitucional, nas mesmas circunstâncias (art. $525 \S \S 12$ e 15).

Ao lado de todos os elementos apresentados como indiciários de um processo civil satisfativo e democrático, é de se reconhecer a sua especial finalidade quando se trata do processo judicial previdenciário. O processo previdenciário versa sobre direitos prestacionais materiais, ou seja, os que se referem às ferramentas de combate e regulação dos riscos sociais, 
permitindo ao indivíduo a manutenção da dignidade ou mínimo social mesmo em situações de efetivação dos referidos riscos.

O processo previdenciário, instrumentaliza-se a partir da falha ou negativa da Administração Pública em conceder, manter e revisar as prestações postas á disposição do indivíduo, caracterizando um ambiente de ofensa ou perigo de ofensa a um direito, expressando, portanto, uma pretensão jurídica, passível de acionamento da jurisdição.

Frente a relevância do objeto de tais processos, há quem defensa a necessidade do reconhecimento da autonomia do processo previdenciário, sendo uma relação processual atípica em face do processo civil comum, pois os direitos postos em análise na referida relação possuem uma importância diferenciada justamente por integrarem o feixe de Direitos Sociais que permitem a manutenção humana do indivíduo em sociedade.

Diante da relevância do direito posto em análise no processo judicial previdenciário, bem como do dever de cooperação na construção do resultado da relação processual, é dizer, a decisão judicial, é inegável o fato de que esta cooperação é elementos indispensável para o caráter satisfativo da decisão judicial. Inclusive, este elemento não se mostra no âmbito da satisfatividade somente após a sua previsão expressa no aparato normativo do CPC, mas já era amplamente reconhecido no âmbito da doutrina e jurisprudência (SAVARIS; SERAÚ JÚNIOR, 2016, p. 13).

É preciso enfatizar esse dever de satisfatividade da resposta jurisdicional no processo previdenciário, outrossim, por peculiaridades processuais deste tipo de demanda. Inicialmente, observa-se que a esmagadora maioria das ações previdenciárias se submetem á competência material constitucional da Justiça Federal, uma vez que versam sobre interesse do Instituto Nacional do Seguro Social - INSS que é uma autarquia federal, portanto, englobando interesse jurídico da União, na forma do art. 109, V, da CF.

Ademais, excluem-se da competência da Justiça Federal, por implicação do mesmo dispositivo constitucional - parte final -, as demandas que versam sobre acidente de trabalho ou sejam de competência especial da Justiça do Trabalho ou Justiça Eleitoral.

Apesar da exceção acerca da competência da Justiça Federal, no que se refere a demanda que trata sobre acidente de trabalho, é fato que a esmagadora maioria das ações previdenciária distribuídas no âmbito do Poder Judiciário brasileiro, tratam de benefícios de natureza estritamente previdenciária, restando para a justiça estadual, de forma residual, as ações que versam sobre benefícios acidentários, que são a minoria. Ocorre que estes benefícios, são essencialmente os que têm como fato gerador a incapacidade laborativa, ou as revisões sobre esses benefícios, quais sejam: auxílio-doença, auxílio-acidente e aposentadoria 
por invalidez, todos decorrentes de acidente de trabalho, o que inclui doença ocupacional (arts. 42 a 47, 59 a 63 e 86, todos da Lei 8.213/91).

Expressando em forma de números, de acordo com o Relatório Anual "Justiça em Números", ano-base 2018, elaborado pelo Conselho Nacional de Justiça (JUSTIÇA EM NÚMEROS, 2018, p. 181), que enumera, dentre outras informações, os cinco assuntos mais tratados em novas demandas distribuídas em todo o Poder Judiciário, no ano de 2017, no âmbito da Justiça Federal, foram distribuídas 2.010.656 (dois milhões e dez mil, seiscentas e cinquenta e seis) novos processos. Deste total, 1.008.248 (um milhão e oito mil, duzentas e quarenta e oito) demandas versaram sobre Direito Previdenciário, o que equivale a cerca de $50,1 \%$ (cinquenta vírgula um por cento) do total dos processos distribuídos para a Justiça Federal. Este percentual equivale ao primeiro e terceiro assuntos mais tratados que são "Benefícios em Espécie/Auxílio-Doença Previdenciário" e Benefícios em Espécie/Aposentadoria por Invalidez".

No âmbito da Justiça Estadual, sequer o assunto referente a benefícios por incapacidade decorrentes de acidente de trabalho, aparecem entre os cinco assuntos mais tratados, o que demonstra que não há o mesmo impacto na atuação desta justiça, como ocorre na Justiça Federal.

O relatório referido apresenta, ainda, que 1.437 .836 (um milhão quatrocentos e trinta e sete mil, oitocentos e trinta e seis) processos, tramitaram na Justiça Federal através do procedimento do Juizado Especial Federal, o que equivale a 71,5\% (setenta e um vírgula cinco por cento) do total de demandas distribuídas nesta justiça (JUSTIÇA EM NÚMEROS, 2018, p. 191).

Pois bem, o que se busca demonstrar através dos números apresentados, é que a esmagadora maioria dos processos que tramitam na Justiça Federal tratando sobre benefícios previdenciários, seguem o rito do Juizado Especial Federal. A razão para isto, decorre do critério de competência em razão do valor da causa estabelecido para os Juizados que, no âmbito federal é de 60 (sessenta) salários-mínimos (art. $3^{\circ}$ da Lei 10.259, de 12 de julho de 2001).

Ademais, diferentemente dos Juizados Especiais Estaduais, onde o critério em razão do valor da causa é relativo, ou seja, mesmo a demanda se enquadrando em valor que caracterizaria a competência do juizado, o jurisdicionado poderia optar se ajuizaria sua demanda através do referido procedimento, ou prosseguiria pelo procedimento comum, no âmbito dos Juizados Especiais Federais, a competência em razão do valor da causa é 
absoluta $^{46}$, não cabendo ao jurisdicionado optar, no caso do valor da causa ser inferior a sessenta salários-mínimos (art. $3^{\circ}, \S 3^{\circ}$ da Lei 10.259/01).

Estas breves considerações feitas acerca da incidência de demandas na Justiça Federal, bem como do procedimento, em sua maioria, adotado no referido órgão, é necessária a ligação dos respectivos dados, com a fundamentação da necessidade de um caráter satisfativo na decisão judicial que engloba a análise de prestações matérias previdenciárias.

Ao obrigar, por critério absoluto, o transcurso do processo pelo Juizado Especial Federal, o legislador retira do jurisdicionado que pleiteia uma prestação previdenciária de cunho material, instrumentos de ordem recursal, em prol da simplificação do procedimento, celeridade e oralidade processuais. É dizer, nos Juizados Especiais Federais não cabem recursos contra decisões interlocutórias - exceto contra decisão que indefere medida cautelar - ou sentenças terminativas, se restringindo o sistema recursal, de forma ordinária, impugnante de decisão monocrática de primeiro grau, ao recurso inominado e aos embargos de declaração (arts. $4^{\circ}$ e $5^{\circ}$ da Lei 10.259/01).

A maioria das demandas em matéria previdenciária, por sua vez, se enquadram no limite de sessenta salários mínimos em razão da prescrição das parcelas vencidas, que é de cinco anos, limitando os efeitos financeiros de eventuais demandas (art. 103, parágrafo único, da Lei 8.213/91).

No segundo grau, em face de acórdão da Turma Recursal, não existem instrumentos recursais ordinários de impugnação, mas somente os Incidentes de Uniformização de Jurisprudência, Nacional e Regional, ou perante o STJ, bem como o Recurso Extraordinário, não cabendo qualquer outro recurso interno ao Colegiado da Turma Recursal.

Percebe-se, assim, que o segurado, em especial aquele que percebe benefício de valor menor, será obrigado a ter a sua demanda tramitada pelo procedimento dos Juizados Especiais Federais, o que implica na retirada de instrumentos de impugnação recursal das decisões de primeiro e segundo grau, reduzindo, assim, as possibilidades de reforma das referidas decisões (SAVARIS; SERAÚ JÚNIOR, 2016, P. 13).

Esta conclusão conduz para a ideia da necessidade uma decisão judicial, seja monocraticamente em primeiro grau, seja por um acórdão, deve ser a mais satisfativa possível, no sentido de garantir ao jurisdicionado/segurado um convencimento da correção da

\footnotetext{
${ }^{46}$ A matéria, inclusive, já foi objeto de ampla discussão judicial, contudo o entendimento pacífico é de que prevalece a competência absoluta em razão do valor da causa, inobstante, ordinariamente, tal critério se revele como relativo. A este respeito vide Informativo 507 do STJ.
} 
resposta jurisdicional, evitando a repropositura da demanda através de nova provocação administrativa, com eventual indeferimento.

Afora os elementos teóricos apresentados, no sentido de que o sistema processual brasileiro apresenta como base a construção cooperativa da decisão judicial, possibilitando uma decisão mais coerente com a realidade e os interesses sociais, portanto, melhor aceita e mais satisfativa, destacam-se os dados empíricos, que revelam um alto grau de ajuizamento de ações tratando de matéria previdenciária, o que se agrava pelo procedimento em que correm estas demandas, o qual, em geral, sacrifica o aprofundamento da análise judicial em prol da celeridade e economia processual.

Implica-se, assim, que o processo judicial, por mais que se preste a dar uma resposta rápida ao indivíduo, não pode se sobrepor à natureza essencial do direito previdenciário, como seu objeto, ou mesmo carecer de uma análise mais aprofundada das demandas que tem como finalidade a análise do direito ao recebimento de algum benefício. Na realidade, mais do que nunca, em matéria de direitos sociais, é essencial que o processo seja um instrumento de efetivação e materialização da paz social. Não um mero concessor ou não de benefícios. Que seja uma ferramenta de quebra da tensão social, de tranquilização dos indivíduos e de soluções materiais.

Por outro lado, como visto na curta análise empírica realizada no presente subtópico, há um alto grau de insatisfação pelos(as) segurados(as), o que leva a uma massificação de demandas judiciais, tornando o Poder Judiciário refém de metas e estatísticas, inclusive como forma de justificação da sua existência e manutenção como estrutura estatal.

Obviamente, este ambiente resta completamente inadequado ao caráter ultimador do Poder Judiciário, como aquele que somente atuará no caso de impossibilidade de resolução da questão de forma autocompositiva, tornando-o, na realidade, refém social do abismo dialógico entre a Função Judicial e a Função Executiva do Estado.

O Poder Judiciário se porta, assim, em um dilema. Fornecer uma tutela jurisdicional materializadora, que efetivamente restitui a paz social e quebra o conflito de forma satisfativa; ou, por outro lado, fornecer uma tutela jurisdicional célere em face do grande número de ações judiciais que versam sobre prestações materiais previdenciárias, no entanto, com base em uma decisão judicial rasa e meramente numérica, onde a materialização e satisfação só se dá quando esta é proferida em favor do segurado.

A exigência de um Poder Judiciário produtivo decorre de uma maior incidência do modelo neoliberal econômico a partir da década de 1970, retirando o Estado, gradativamente, da posição de interventor na economia. Obviamente, após a Segunda Guerra Mundial, a 
intervenção estatal na economia, como modelo de convivência Estado-sociedade, se fazia imprescindível para a reconstrução social, havendo, obviamente, ideais liberais relacionados ao livre mercado, especialmente pela manutenção onerosa da estrutura estatal interventiva de corrente do mal gerenciamento dos elementos estruturais (GURGEL, 2003, p. 120), sendo imperioso um equilíbrio entre a concorrência "atomística" e o dirigimos central (HAYEK, 1990, p. 67).

A concessão de um viés ideológico voltado para a efetividade do Poder Judiciário, através de elementos de economia e celeridade processual, com a criação do Conselho Nacional de Justiça, bem como as demais modificações introduzidas pela Emenda Constitucional n 45, se deu por influência direta do Documento no 319 do Banco Mundial, que estabeleceu bases ideológicas para a condução do Poder Judiciário na América Latina e no Caribe, observando diretrizes neoliberais (CORDEIRO, 2016, p. 61). De acordo com o referido documento, a modernização do Judiciário no âmbito do MERCOSUL se impunha em razão da necessidade de pacificação de princípios e regras na decisão e harmonização de questões comerciais e econômicas, implicando em um Poder Judiciário que, nas suas decisões, aplica interpretações de acordo com padrões regionais e internacionais (BANCO MUNDIAL, 1996, p. 18).

A questão seria a harmonização entre o contato do Poder Judiciário com a economia e a sua atuação na proteção de direitos e garantias individuais. A previsibilidade das decisões judiciais, por sua vez, pelas orientações do Documento Técnico citado, conduziria a observância de padrões regionais e internacionais, não sendo claro que estabeleceria esses padrões e até que ponto poderiam influir/vincular a previsibilidade das decisões. Por sua vez, a condução de uma atuação estatal voltada para um capitalismo mundial, a partir dos padrões referidos, pode servir de coberta para os reais interesses de organizações bilaterais ou multilaterais como o Fundo Monetário Internacional - FMI, Banco Mundial e Organização Mundial do Comércio, as quais se revelam como "estruturas mundiais de poder" (IANNI, 2004, p. 40).

Ocorre que a adoção das diretrizes estabelecidas a partir dos influxos neoliberais referidos cria a imagem de um Poder Judiciário meramente quantitativo, com a prevalência da maximização de resultados em face da devida prestação da tutela jurisdicional satisfativa. Esta sobreposição ocasiona uma submissão da pacificação social pelo Judiciário, como dever, assim como da própria função de reconstrução e materialização da Constituição. 


\section{CONSIDERAÇÕES FINAIS}

A tutela jurisdicional, mais do que célere e eficiente, deve corresponder à efetiva resolução do conflito social, da crise posta em análise em face do Judiciário.

Em matéria de Direito à Previdência, o processo previdenciário deve observância direta à impossibilidade de retrocesso social de tal direito, bem como de evitar a sobreposição da celeridade em face da análise satisfativa e materializadora do Direito.

Viu-se que a celeridade, inobstante ser um elemento caro ao processo, como forma de garantir uma confiança e maior legitimidade do Poder Judiciário, foi introduzida na processualística brasileira a partir de interesses que não dizem respeito somente à resposta social atribuída ao Judiciário em face do cidadão, mas também a partir de interesses de mercado, de economia, para possibilitar o desenvolvimento e prosperidade econômica.

A sobreposição mencionada torna-se perigosa a partir do momento em que se tem no Poder Judiciário a via de acesso para uma análise mais aprofundada do direito do segurado, ante a inefetividade da Administração Previdenciária.

Portanto, é imprescindível que seja desenvolvida uma tutela jurisdicional, no que se refere ao Direito à Previdência, voltada para o efetivo esvaziamento dos conflitos sociais, restabelecendo a situação de paz e prosperidade, indo além dos interesses meramente subjetivos das partes.

É essencial que essa conduta tenha regência na atividade jurisdicional, observando que o objetivo da resposta a ser dada é restabelecer uma situação de normalidade, em face do surgimento de um risco social provocador de uma situação de marginalização social, prejudicial para toda a coletividade.

O vetor construtivo e materializador da tutela jurisdicional transparece do Código de Processo Civil, a partir de elementos normativos que fornecem liberdade de negociação processual ás partes, bem como impõem o dever de cooperação, boa-fé e solidariedade na construção da decisão judicial.

Assim, torna-se imperiosa a adequação do Processo Previdenciário a estes ditames, garantindo uma resposta satisfativa, sem o comprometimento da celeridade e evitando a rejudicialização, bem como a manutenção de situação de conflito material no âmbito da sociedade.

\section{REFERÊNCIAS}


AIRES FILHO, Durval. Direito Público em Seis Tempos Teóricos Relevantes e Atuais. Florianópolis: FUNJAB, 2014, p. 162.

ARAÚJO CINTRA, Antonio Carlos de; GRINOVER, Ada Pellegrini; DINAMARCO, Cândido Rangel. Teoria Geral do Processo, $31^{\text {a }}$ Ed., Malheiros Editores, São Paulo, 2015, p. 46.

BANCO MUNDIAL, Documento técnico no 319, O Setor Judiciário na América Latina e no Caribe - Elementos para Reforma. Washington, 1996, p. 18.

BERCOVICCI, G. Constituição e estado de exceção permanente. Atualidade de Weimar. Rio de Janeiro: Azougue, 2004. p. 179.

BOROWSKI, M. La estructura de los derechos fundamentales. Bogotá: Universidad Externado de Colombia, 2003

CANOTILHO, José Joaquim. Direito Constitucional e teoria da constituição. Coimbra: Almedina, 2006

CORDEIRO, Wagner Freitas. A Produtividade No Poder Judiciário E a Construção Da Justiça Quantitativa. Dissertação (Mestrado em Administração) - Faculdade de Administração, Universidade Federal Fluminense, Rio de Janeiro, 2016, p. 61, encontrada no endereço eletrônico: https://app.uff.br/riuff/handle/1/2031. Acesso em: 2018-11-15.

DIDIER JÚNIOR, Fredie. Curso de Direito Processual Civil: Introdução ao Direito Processual Civil, parte geral e processo de conhecimento. 19a Ed., Salvador: Jus Podivm, 2017, p. 620.

DINAMARCO, Cândido Rangel; LOPES, Bruno Vasconcelos Carrilho. Teoria Geral do Novo Processo Civil, $3^{\text {a }}$ Ed. - São Paulo, Malheiros Editores, 2018, p. 77.

GURGEL, Cláudio Roberto Marques. A gerência do pensamento: gestão contemporânea e consciência neoliberal, São Paulo: Cortez, 2003, p. 120.

HAYEK, Friedrich August von. O caminho da servidão, tradução e revisão Anna Maria Capovilla, José Ítalo Stelle e Liane de Morais Ribeiro. - 5. ed. - Rio de Janeiro: Institiuo Liberal, 1990, p. 67. 
IANNI, Octavio. Capitalismo, violência e terrorismo, Civilização Brasileira, Rio de Janeiro, 2004, p. 40.

Justiça em Números 2018: ano-base 2017/Conselho Nacional de Justiça - Brasília: CNJ, 2018, p. 181.

MENDES, Gilmar Ferreira; COELHO, Inocêncio Mártires; GONET BRANCO, Paulo Gustavo. Hermenêutica Constitucional e Direitos Fundamentais, 1. ed., 2. tir. 2002, Brasília Jurídica, p. 127- 128

MORAIS, J. L. B. de. As crises do Estado e da Constituição e a transformação espacial dos direitos humanos. Porto Alegre: Livraria do Advogado, 2002, p. 29.

J. L. B. de. Crises do Estado, democracia política e possibilidades de consolidação da proposta constitucional. In: CANOTILHO, J. J. G.; STRECK, L. L. Boletim da Faculdade de Direito STVDIA IVRIDICA, p. 89 - Entre Discursos e Culturas Jurídicas. Universidade de Coimbra. Coimbra, 2006, p. 22.

MOREIRA, José Carlos Barbosa. Os Princípios do direito processual civil na constituição de 1988. In: Temas de direito processual. São Paulo: Saraiva, 1993. p. 243

RAWLS, J. Uma teoria da justiça. Oxford: Oxford University, 1980

SARLET, Ingo Wolfgang. A eficácia dos direitos fundamentais. $8^{\mathrm{a}}$ ed., Porto Alegre, Livraria do Advogado, 2007, 457-460

SAVARIS, José Antonio. Uma teoria da decisão judicial da Previdência Social: contributo para superação da prática utilitarista. 2010. Tese (Doutorado em Direito do Trabalho) Faculdade de Direito, Universidade de São Paulo, São Paulo, 2010, p. 103. doi:10.11606/T.2.2010.tde-25082011-161508. Acesso em: 2018-11-08.

José Antonio; SERAU JÚNIOR, Marco Aurélio, Coordenadores. Os impactos do novo CPC nas ações previdenciárias, LTr, São Paulo, 2016, p. 13.

SCHWARZ, Rodrigo; FLORENCIO THOMÉ, Candy. Vedação ao Retrocesso e Seguridade Social: a Proteção da Segurança e da Confiança, a Reserva do Possível e a não Regressividade em Matéria de Direitos Fundamentais Sociais. Revista de Direitos Sociais, Seguridade e Previdência Social, 2017, p. 03. 2. 10.21902/2525-9865/2016.v2i2.1222. 
SILVA, Ovídio A. Bapstista da. Fundamentação das sentenças como garantia constitucional. Revista do Instituto de Hermenêutica Jurídica, Porto Alegre, v. 1, n. 4, p. 323352, 2006. p. 340.

TARUFFO, Michelle. A motivação da sentença civil. Tradução de Daniel Mitidiero, Rafael Abreu, Vitor de Paula Ramos. 1ª ed. São Paulo: Marcial Pons, 2015, p. 237.

TAVARES, Marcelo Leonardo. Direito Previdenciário: regime geral de previdência social e regras constitucionais dos regimes próprios de previdência social. 13. ed. rev. e ampl. e atual. Niteroi, RJ: Impetus, 2011.

WEBER, Max. O direito na economia e na sociedade. Trad. Marsely de Marco Martins Dantas. $1^{a}$ Ed. São Paulo: Ícone, 2011, p. 41

\title{
THE PREVENTIVE JUDICIAL PROCESS, QUANTITATIVE JUSTICE AND THE SATISFACTION OF JURISDICTION
}

\begin{abstract}
Jurisdiction should no longer serve only the subjective interest of the parties, but in the construction of the judicial decision, the whole society is interested. In terms of Social Security Rights, the activity of the judge must override the materialization and construction of the Law in the face of speed and procedural efficiency, under penalty of not solving the conflict nor restoring social peace. In this respect, judicial protection should consider the impossibility of regression in social matters, as well as neoliberal inflows in the construction of a concept of celerity, noting that the attainment of the judicial decision pertains to the whole social body, so that if the individual is not effectively protected by the Judiciary, it will not do anything to achieve goals and the massive trial of processes. In this way, the present study, through bibliographical research and analysis of statistical data, considers satisfaction and speed factor in the face of the need for a materialized and reconstructed Welfare Rights.
\end{abstract}

Keywords: Right to Social Security. Satisfaction. Celerity. Process. 